\title{
Entretien avec Peter Brook
}

\section{(2) OpenEdition}

1 Journals

\section{Édition électronique}

URL : http://journals.openedition.org/shakespeare/1244

DOI : $10.4000 /$ shakespeare.1244

ISSN : 2271-6424

Éditeur

Société Française Shakespeare

\section{Édition imprimée}

Date de publication : 1 novembre 1992

Pagination : 173-178

Référence électronique

"Entretien avec Peter Brook », Actes des congrès de la Société française Shakespeare [En ligne],

10 | 1992, mis en ligne le 01 janvier 2007, consulté le 06 mai 2019. URL : http://

journals.openedition.org/shakespeare/1244; DOI : 10.4000/shakespeare.1244

Ce document a été généré automatiquement le 6 mai 2019.

(c) SFS 


\section{Entretien avec Peter Brook}

